\title{
Acute diphenylhydantoin and primidone poisoning treated by peritoneal dialysis
}

\author{
A. A. D. Blair, J. F. HALlPIKE 1 , P. T. LASCElles, AND D. L. Wingate \\ From the National Hospital, Queen Square, and \\ the Middlesex Hospital, London
}

Since diphenylhydantoin (Phenytoin) was introduced in 1938 for the treatment of epilepsy it has become one of the most widely used anticonvulsant drugs and retains a reputation for considerable therapeutic safety. However, knowledge of its toxicity is increasing and an extensive and diverse literature now exists on the subject. The occurrence of blood dyscrasias and other serious complications of treatment with diphenylhydantoin have been reviewed by Sparberg (1963) and the use of this drug together with other anticonvulsants has also been causally related to megaloblastosis with associated folate deficiency (Reynolds, Milner, Matthews, and Chanarin, 1966) in an important proportion of patients receiving these drugs for lengthy periods.

Commonly encountered signs of neurotoxicity are nystagmus, ataxia, and dysarthria, which are likely to be present with blood levels of diphenylhydantoin exceeding $20 \mu \mathrm{g} / \mathrm{ml}$. (Kutt, Winters, Kokenge, and McDowell, 1964). A number of patients are now known to have developed permanent cerebellar damage following both acute (Theil, Richter, Powell, and Doolan, 1961) and chronic (Utterback, 1958) diphenylhydantoin intoxication. The disturbances of cerebellar function were sometimes severe and the histological evidence in both man and animals that diphenylhydantoin produces Purkinje cell damage has been discussed by Kokenge, Kutt, and McDowell (1965).

The features of primidone (Mysoline) overdosage have been attributed to the metabolic conversion of primidone to phenobarbitone, and high body fluid barbiturate levels are found in cases of primidone poisoning (Plaa, Fujimoto, and Hine, 1958; Bogan, Rentoul, and Smith, 1965). In contrast with diphenylhydantoin, permanent damage to the nervous system has not been reported after primidone intoxication and complete recovery is the rule with withdrawal of the drug.

There are therefore grounds for believing that an

'Present address and requests for reprints: Department of Pathology, Guy's Hospital Medical School, London Bridge, S.E.1. early and rapid reduction in the blood and tissue $\frac{\bar{\sigma}}{\sigma}$ concentrations of diphenylhydantoin after large $\stackrel{\mathbb{Q}}{\varrho}$ overdoses are of greater urgency than had been realized until recently. We report here and discuss the outcome of peritoneal dialysis in a patient whose pre-dialysis blood diphenylhydantion level, following a deliberate overdose of both this drug and primidone, considerably exceeded those previously reported.

METHODS

Diphenylhydantoin in serum, urine, and peritonea dialysate was estimated by the ultraviolet spectrophoto metric method of Wallace, Biggs, and Dahl (1965). This has the advantage over previously described methods of specificity and of high recovery values. Following a simple extraction procedure hydrolysis of the hydantoin ring if strong alkali is followed by a Hofmann degradation of the resulting amide to yield a steam-distillable product which has a high molar absorptivity with a maximum at $257 \mathrm{~m} \mu$ In vitro observations failed to show any effects of primidone on the diphenylhydantoin determinations by this method. Caeruloplasmin was estimated by the method of Houchin (1958) and the investigation into primidone crystalluria was kindly undertaken by Imperial Chemical Industries Ltd., using an AEI MS 9 mass spectrometer.

\section{CASE REPORT}

A male telephonist, aged 20, was admitted to East Ham Memorial Hospital, under the care of Dr. H. W. Salmon, in June 1967 having collapsed in a nearby cinema an hour after taking a large quantity of anticonvulsant drugs amounting to approximately $12 \mathrm{~g}$ diphenylhydantoin and $15 \mathrm{~g}$ primidone. He had suffered from idiopathic epilepsy since the age of 16 and in previous months had been instructed to take $\mathbf{4 0 0} \mathrm{mg}$ diphenylhydantoin (Epanutin) and $500 \mathrm{mg}$ primidone daily. A history of two previous suicide attempts was ultimately obtained; he also had a poor school and work record and was estranged from his parents. On the day following the overdose he was transferred to the National Hospital (N.H. A36766) under the care of Dr. Michael Kremer.

Examination then showed him to be a muscular young man (weight $70 \mathrm{~kg}$ ) and apparently well nourished. $\mathrm{He}$ 
was disorientated but occasional lucid answers to questions were obtained and essential details of his suicide attempt could be established. Rocking movements of his head were frequent and jerking of the limbs required restraint. There was a coarse head and arm ataxia when he tried to sit up. He had a divergent strabismus with gross deficiency in reflex and voluntary conjugate eye movements. No spontaneous nystagmus was observed. Pupillary responses were present and he was able to swallow. Power in the limbs was good, tendon reflexes were present and plantar responses flexor. There was little response to pin prick or other painful stimuli. Blood pressure was $125 / 90$; respiratory and pulse rates were normal, together with the remaining physical examination.

The results of investigations on admission to the National Hospital on 16 June 1967 were: proteinuria with a crystalline urinary deposit; haemoglobin $17.3 \mathrm{~g} / 100 \mathrm{ml}$., PCV 50\%, white cells and platelets normal and ESR $1 \mathrm{~mm} / 1 \mathrm{hr}$; plasma sodium, 146 and potassium $4 \cdot 1$ m-equiv/1. Blood urea $21 \mathrm{mg} / 100 \mathrm{ml}$. Alkaline phosphatase 57 i.u./1., serum proteins, electrophoresis, and flocculation tests of liver function normal. Serum barbiturate (expressed as diethyl-barbituric acid) $7 \cdot 1$ $\mathrm{mg} / 100 \mathrm{ml}$. The results of ${ }^{131}$ iodine-triiodothyronine resin uptake, caeruloplasmin and protein bound iodine estimations are shown in the Table and compared with the results obtained at a later date. Radiographs of the skull and chest were normal. The cerebrospinal fluid contained $45 \mathrm{mg}$ protein $/ 100 \mathrm{ml}$. and 6 lymphocytes $/ \mathrm{cmm}$.

On the day after admission to the National Hospital his level of consciousness deteriorated with continuing extreme restlessness. The serum barbiturate had fallen to $2 \cdot 1 \mathrm{mg} / 100 \mathrm{ml}$, and with the finding of a diphenylhydantoin blood level of $60 \mu \mathrm{g} / \mathrm{ml}$. (see Fig. 1) for 16 June he was transferred to the Middlesex Hospital (G. 81995) for peritoneal dialysis.

The results of dialysis, which was started at 0100 on 18 June and continued for 35 hours, are shown graphically. Twenty-one volumes of dialysing fluid (sodium lactate $5 \mathrm{~g}$, sodium chloride $5.6 \mathrm{~g}$, calcium chloride $0.38 \mathrm{~g}$, magnesium chloride $0.15 \mathrm{~g}$, dextrose $15 \mathrm{~g}$, and water to 11) were employed in hourly cycles with addition of potassium at intervals. Intravenous fluids were regulated with reference to urinary output, PCV, and plasma electrolyte changes during dialysis. He was sedated with intramuscular paraldehyde and received vitamin $\mathbf{B}_{12}$ $1.0 \mathrm{mg}$ intramuscularly daily and folic acid $15 \mathrm{mg}$ intramuscularly daily. Blood samples and aliquots of urine and dialysate were collected for diphenylhydantoin estimations.

Towards the end of dialysis there was clinical improvement with a return of swallowing and urinary continence. The fall in blood diphenylhydantoin and loss of the drug in dialysate and urine which occurred at this time are shown in the graph. He remained unco-operative and features of marked trunçal and limb ataxia were noted together with nystagmus on lateral gaze. But by 20 June he was rational and able to converse.

On readmission to the National Hospital (23 June) he was able to give a full account of events leading up to the suicide attempt but remained amnesic for the four days

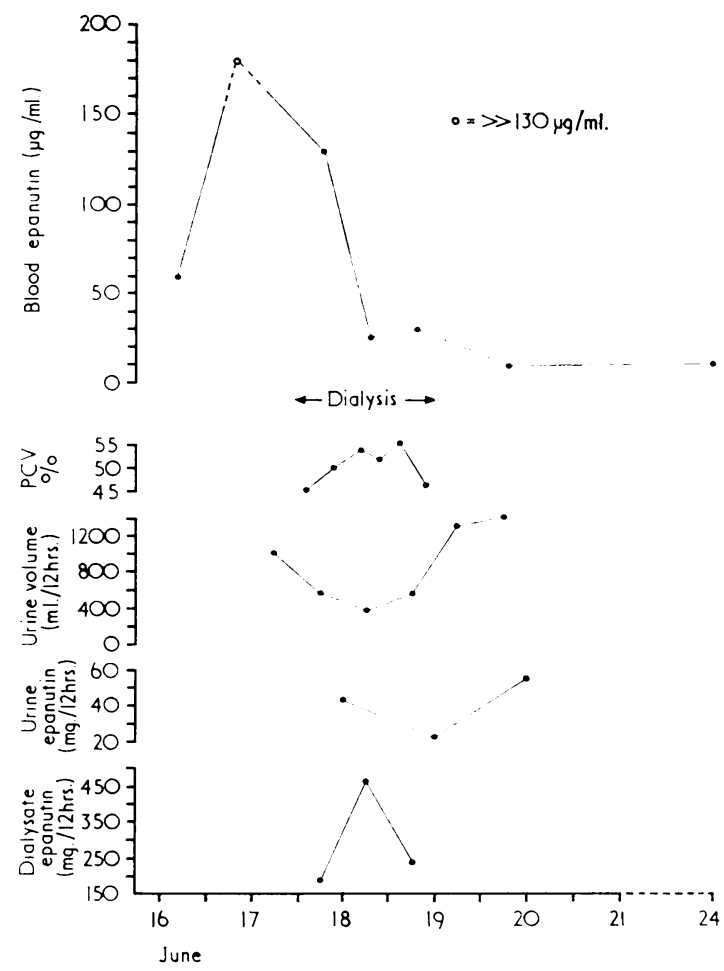

FIG. 1. Dialysis chart.

after this. There was nystagmus but ocular movements were full. Evidence of moderate cerebellar dysfunction was present but disability was slight. Tendon reflexes could be elicited with reinforcement and the plantar responses remained flexor. Sensation was intact.

Liver function tests were again normal and the BSP retention at $45 \mathrm{~min}$ was $3.5 \%$; serum $\mathrm{B}_{12} 690 \mu \mu \mathrm{g} / \mathrm{ml}$. and serum folic acid $13.6 \mu \mathrm{g} / \mathrm{ml}$.; serum calcium $9.4 \mathrm{mg} /$ $100 \mathrm{ml}$. In a standard D-xylose absorption test the $5 \mathrm{hr}$ urinary excretion was $4.5 \mathrm{~g}$ and the 90 -min serum level was $37 \mathrm{mg} / 100 \mathrm{ml}$. The first part of a Schilling test was normal $(20.9 \%$ excretion of the tracer dose in $24 \mathrm{hr})$. The creatine clearance was $114 \mathrm{ml} / \mathrm{min}$. Further values for ${ }^{131}$ iodine-triiodothyronine-resin uptake, caeruloplasmin and protein bound iodine (Table I) were obtained and will be discussed.

\section{TABLE I}

${ }^{131}$ IODINE-TRHODOTHYRONINE-RESIN UPTAKE, CAERULOPLASMIN AND PROTEIN BOUND IODINE IN BLOOD DURING (A) AND SIX WEEKS AFTER (B) PERIOD OF ACUTE DIPHENYLHYDANTOIN INTOXICATION

\begin{tabular}{llll} 
Investigation & $A$ & $B$ & Normal range \\
\hline $\begin{array}{l}\text { 131 Iodine-triiodothryo- } \\
\text { nine resin uptake }\end{array}$ & $40.3 \% 41 \cdot 3 \%$ & $26 \cdot 3 \%$ & $25-35 \%$ \\
$\begin{array}{l}\text { Caeruloplasmin } \\
\text { mg/100 ml. }\end{array}$ & 20.5 & $25 \cdot 6$ & $23-44 \mathrm{mg} / 100 \mathrm{ml}$. \\
$\begin{array}{l}\text { Protein bound iodine } \\
\mu \mathrm{g} / 100 \mathrm{ml} .\end{array}$ & 2.9 & 5.4 & $4-8 \mu \mathrm{g} / 100 \mathrm{ml}$.
\end{tabular}


The results of nerve conduction studies (Dr. R. S. Kocen) carried out 10 days after dialysis showed a motorconduction velocity in the right lateral popliteal nerve of $51 \mathrm{~m} / \mathrm{sec}$ (normal range 39 to $52 \mathrm{~m} / \mathrm{sec}$ ). Sensory nerve action potentials recorded with a needle electrode from the right lateral popliteal nerve at the knee in response to stimulation of the anterior tibial nerve at the ankle were normal. Caloric, optokinetic responses, and pure tone audiograms (Dr. M. R. Dix) were also normal at this time.

On discharge from hospital, five weeks after the overdose, he was symptom free and without evidence of cerebellar or other neurological deficiency. Psychiatric advice had been sought and attempts to achieve social rehabilitation were made. Anticonvulsant medication was restricted to $120 \mathrm{mg}$ phenobarbitone/day.

\section{DISCUSSION}

Cases of poisoning with diphenylhydantoin in which death was related to central nervous system damage have been described by Tichner and Enselberg (1951), Schmeiser (1952), Krause (1959) and Laubscher (1966). In these, in cases where recovery occurred, and in the present case restless and at times violent behaviour were important features of the clinical state during the period of acute intoxication. Although nystagmus and defective convergence are common, external ophthalmoplegia is rarely seen in diphenylhydantoin intoxication alone and it is of interest, in this respect, that in three of the four cases of external ophthalmoplegia associated with diphenylhydantoin or primidone intoxication described by Orth, Almeida, Walsh, and Honda (1967) overdoses of both these drugs occurred.

The value of dialysis in treating diphenylhydantoin poisoning was suggested by Schreiner (1958) in his report of the case of a 2 year-old Negro boy whose complete recovery from a stage of deep stupor with periodic respirations seemed clearly related to haemodialysis, although biochemical data on blood and dialysate diphenylhydantoin levels were not obtained. Theil et al. (1961) have reported in detail the results of haemodialysis carried out in an 18 year-old woman 138 hours after a large overdose of diphenylhydantoin and phenobarbitone. The predialysis diphenylhydantoin blood level was $50 \mu \mathrm{g} / \mathrm{ml}$. (three times the upper limit of normal for patients on diphenylhydantoin therapy in their laboratory) and the immediate post-dialysis figure was $4 \mu \mathrm{g} / \mathrm{ml}$. Clinical improvement in this case was slow with intellectual deficit persisting after several weeks. In the present case diaylsis was started some 55 hours after the overdose and clinical improvement was obvious after 48 hours. Within two weeks he was without neurological abnormality. Paraldehyde proved a safe and effective sedative during the dialysis procedure.
Primidone was not thought to have been a major factor in producing the clinical state on the day $\mathbb{D}$ following admission to the National Hospital. By this time the serum barbiturate had fallen from the initial value of $7 \cdot 1 \mathrm{mg} / 100 \mathrm{ml}$. to a level unlikely to be seriously toxic at a time when the patient's condition $\bigcirc$ was worsening. Specific identification of primidone crystals in the urine at this time by mass spectrometry supports the previous inference of Morley and $\stackrel{0}{7}$ Wynne (1957) in respect of the crystalluria they observed in a child with acute primidone poisoning. $\overrightarrow{\bar{F}}$

On the basis of the findings of Reynolds et al. (1966) and Reynolds, Hallpike, Phillips, and $\frac{1}{\circ}$ Matthews (1965) concerning the effect of diphenyl- $\frac{\bar{\omega}}{\bar{\omega}}$ hydantoin together with certain other anticonvuls- $\overparen{\nabla}$ ants in producing folate and vitamin $B_{12}$ deficiency $\frac{\Omega}{v}$ associated with reversible impairment in intestinal o absorption large doses of folate and vitamin $B_{12}$ were $\vec{\circ}$ administered parenterally during and after dialysis. $\vec{\overrightarrow{ }}$ D-xylose and Schilling tests carried out subsequently were normal.

The finding of a low protein-bound iodine during the acute phase of intoxication is in line with the $\omega$ observations of Oppenheimer, Fisher, Nelson, and $\overrightarrow{i r}$ Jailer (1961) and those of Cantu and Schwab (1966) of Although the change in caeruloplasmin between th 0 time of admission and the recovery peiod was no 을 significant the alteration in the in-vitro $\mathrm{T}_{3}$ value duß ing the same period was marked and could bo attributed to competitive binding to protein by the drug.

It can be concluded that dialysis has a part to play in the management of acute diphenylhydantoi poisoning, and the extreme restlessness of most $\infty$ patients during severe intoxication should not result in this procedure being delayed-particularly if laboratory confirmation of seriously toxic blood levels of diphenylhydantoin be obtained.

\section{SUMMARY}

The case is reported of the successful treatment by peritoneal dialysis of a 20-year-old man after attempted suicide with diphenylhydantoin and primidone. The risks of damage to the central nervous system by exposure to toxic levels of diphenylhydantoin are considered and the importance of early dialysis in severe acute poisoning is emphasized.

We are grateful to Dr. Michael Kremer, Dr. H. W. Salmon, and the Medical Committee of the National 은 Hospital, Queen Square, for permission to publish this case. We also wish to thank ICI for their co-operation in o the identification of primidone and Mr. S. G. Pophale for the diphenylhydantoin assays in Professor Cumings's o laboratory. The illustrations were prepared by the $N$ National Hospital Department of Medical Photography. 


\section{REFERENCES}

Bogan, J., Rentoul, E., and Smith, H. (1965). Fatal Poisoning by Primidone. J. forens. Sci. Soc., 5, 97-98.

Cantu, R. C., and Schwab, R. S. (1966). Caeruloplasmin rise and PBI fall in serum due to diphenylhydantoin. Arch. Neurol. (Chic.), $15,393-396$.

Houchin, O. B. (1958). A rapid colorimetric method for the quantitative determination of copper oxidase activity (ceruloplasmin). Clin. Chem., 4, 519-523.

Kokenge, R., Kutt, H., and McDowell, F. (1965). Neurological sequelae following Dilantin overdose in a patient and in experimental animals. Neurology (Minneap.), 15, 823-829.

Krause, H. (1959). Leptioinvergiftung mit tödlichlem Ausgang. $Z$. inn. Med., 14, 353-354.

Kutt, H., Winters, W., Kokenge, R., and McDowell, F. (1964). Diphenylhydantoin metabolism, blood levels, and toxicity. Arch. Neurol. (Chic.), 11, 642-648.

Laubscher, F. A. (1966). Fatal diphenylhydantoin poisoning. J. Amer. med. Ass., 198, 1120-1121.

Morley, D., and Wynne, N. A. (1957). Acute Primidone poisoning in a child. Brit. med. J., 1, 90.

Oppenheimer, J. H., Fisher, L. V., Nelson, K. M., and Jailer, J. W. (1961). Depression of the serum protein-bound iodine level by diphenylhydantoin. J. clin. Endocrinol., 21, 252-262.

Orth, D. N., Almeida, H., Walsh, F. B., and Honda, M. (1967). Ophthalmoplegia resulting from diphenylhydantoin and primidone intoxication. J. Amer. med. Ass., 201, 225-227.
Plaa, G. L., Fujimoto, J. M., and Hine, C. H. (1958). Intoxication from Primidone due to its biotransformation to Phenobarbital. Ibid., 168, 1769-1770.

Reynolds, E. H., Hallpike, J. F., Phillips, B. M., and Matthews, D. M. (1965). Reversible absorptive defects in anticonvulsant megaloblastic anaemia. J. clin. Path., 18, 593-598.

—, Milner, G., Matthews, D. M., and Chanarin, I. (1966). Anticonvulsant therapy, megaloblastic haemopoiesis and folic acid metabolism. Quart. J. Med., 35, 521-537.

Schmeiser, M. (1952). Tödliche Vergiftung mit Zentropil beimi Kind. Kindeärztl. Prax., 20, 158-161.

Schreiner, G. E. (1958). The role of hemodialysis (artificial kidney) in acute poisoning. Arch. intern. Med., 102, 896-913.

Sparberg, M. (1963). Diagnostically confusing complications of Diphenylhydantoin therapy. Ibid., 59, 914-930.

Theil, G. B., Richter, R. W., Powell, M. R., and Doolan, P. D. (1961) Acute Dilantin poisoning. Neurology (Minneap.), 11, 138-142.

Tichner, J. B., and Enselberg, C. D. (1951). Suicidal Dilantin (sodium diphenylhydantoin) poisoning. New Engl. J. Med., 245, 723-725.

Utterback, R. A. (1958). Parenchymatous cerebellar degeneration complicating diphenylhydantoin (Dilantin) therapy. Arch. Neurol. Psychiat. (Chic.), 80, 180-181.

Wallace, J., Biggs, J., and Dahl, E. V. (1965). Determination of diphenylhydantoin by ultraviolet spectrophotometry. Anal. Chem., 37, 410-413. 